\title{
RESENHA SOBRE ESCRITA E INTERAÇÃO DA OBRA LER E ESCREVER: ESTRATÉGIAS DE PRODUÇÃO TEXTUAL
}

\author{
Juliana Behrends de Souza Cerqueira ${ }^{1}$
}

$\mathrm{KOCH}$, Ingedore Villaça; ELIAS, Vanda Maria. Escrita e interação. In: Ler e escrever: estratégias de produção textual. 2 ed. São Paulo: Contexto, 2012, p. 31-52.

As autoras Ingedore Villaça Koch e Vanda Maria Elias produziram a obra Ler e escrever: estratégias de produção textual com o objetivo de "estabelecer uma ponte entre teorias sobre texto e escrita e práticas de ensino" (p.9), demonstrando interesse em trazer os estudos teóricos sociocognitivistas e interacionais da linguagem para o desenvolvimento progressivo da escrita, de forma mais prática e acessível. Importante destacar que Ingedore Villaça Koch é professora livre-docente em Análise do Discurso pela Unicamp, onde atua como professora titular do Departamento de Linguística e implantou, nessa instituição, a área de Linguística Textual. A professora Vanda Maria Elias é associada de Língua Portuguesa na graduação e pós-graduação da PUC-SP, onde realizou seu mestrado e doutorado. Também coordena e ministra aulas no curso de Língua Portuguesa, via internet, oferecidos pela Cogeae/PUC-SP. Ambas realizam pesquisas relacionadas à leitura, à produção de textos e ao ensino de língua portuguesa.

As autoras iniciam o capítulo com a interrogativa $O$ que é a escrita? provocando um debate acerca do real significado da escrita. Argumentam que a resposta para essa pergunta é uma tarefa difícil, visto que escrever envolve aspectos de natureza linguística, cognitiva, pragmática, sócio-histórica e cultural. Afirmam que hoje, diferentemente de tempos passados, a escrita faz parte da

\footnotetext{
${ }^{1}$ Possui graduação em Português/Inglês pela Fundação Educacional Unificada Campograndense (2005), pós-graduação em Língua Portuguesa pelo Liceu Literário Português (2007), mestrado em Letras na UFRRJ (2018), doutorado em Ciências da Educação na Universidad Interamericana - PY (2020), aperfeiçoamento em Ensino de Língua Portuguesa/ Literatura CEDERJ (2012) e Tecnologia Assistiva, Projetos e Acessibilidade: Promovendo a Inclusão UNESP (2010). Atualmente, é professora regente de Língua Portuguesa e Literatura no Colégio Pedro II, Campus Realengo II.
} 


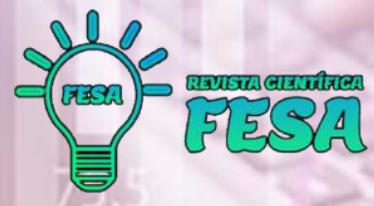

vida de todos, pois os indivíduos são constantemente solicitados a escrever e a ler textos de vários gêneros, comprovando a importância da escrita. Citam Barréde-Miniac (2006, p. 38) para reforçar essa ideia, afirmando que "hoje, a escrita não é mais domínio exclusivo dos escrivães e dos eruditos. [...] A prática da escrita de fato se generalizou: além dos trabalhos escolares ou eruditos, é utilizada para o trabalho, a comunicação, a gestão da vida pessoal e doméstica". Trazem alguns mitos sobre a escrita, tais como "escrita é inspiração", "escrita é uma atividade para poucos privilegiados", "escrita é expressão do pensamento", entre outros.

Na sequência do capítulo, são apresentados três tópicos importantes em relação à escrita: a escrita com foco na língua, foco no escritor e foco na interação. Na seção destinada ao foco na língua, afirmam que a linguagem é encarada como sistema pronto e o escritor deve apenas se apropriar dele, não Ihe sendo permitido o poder de interferência. Sendo assim, a compreensão fundamenta-se no que foi escrito, não cabendo a aplicação da noção dos implícitos.

$\mathrm{Na}$ concepção de sujeito como (pré) determinado pelo sistema, o texto é visto como simples produto de uma codificação realizada pelo escritor a ser decodificada pelo leitor, bastando a ambos, para tanto, 0 conhecimento do código utilizado (KOCH; ELIAS, 2012, p. 33).

Ao falar da escrita com foco no escritor, Koch e Elias afirmam que, nessa concepção, escrever é "expressar o pensamento no papel" (p.33). Aqui, o escritor vê na escrita um mecanismo de expressão de seus pensamentos, sendo ele o "senhor absoluto de suas ações" (p.33) sem considerar as vivências do leitor. Koch e Elias ainda definem que o escritor é um "sujeito psicológico, individual, dono e controlador de sua vontade e ações" (p.33).

No tópico seguinte, ao abordarem a escrita como foco na interação, diferentemente das concepções anteriores, o escritor, ao desenvolver seu texto, não pensa apenas nas regras da língua e em suas intenções, mas pensa também no seu leitor. Nessa concepção interacional, ressaltam que: 
[...] tanto aquele que escreve como aquele para quem escreve são vistos como autores/construtores sociais, sujeitos ativos que dialogicamente - se constroem e são construídos no texto, este considerando um evento comunicativo para o qual concorrem aspectos linguísticos, cognitivos, sociais e interacionais (BEAUGRAND, 1997 apud KOCH; ELIAS, 2012, p. 34).

Koch e Elias afirmam que, ao escrever, o autor preocupa-se com a interação, leva em conta que o leitor também faz parte desse processo interacional, dessa troca de conhecimentos, sem deixar as regras de lado, contudo, essas deixam de ser a parte mais importante no processo de composição do texto.

Após a definição desses três diferentes focos, as autoras apresentam a abordagem sobre a escrita relacionada à ativação dos conhecimentos, mostrando que, ao escrever, o autor recorre a diversas informações presentes em sua memória, para assim desenvolver a escrita. As autoras nomeiam esses conhecimentos como: conhecimento linguístico, conhecimento enciclopédico, conhecimento de textos e conhecimentos interacionais.

No conhecimento linguístico, a atividade de escrita foca nos aspectos relacionados à ortografia, à gramática e ao léxico da língua. Esses conhecimentos facilitam a comunicação e a interação entre escritor/leitor, uma vez que até mesmo uma palavra usada indevidamente prejudica a mensagem que se deseja repassar, pois possuir conhecimento de "[...] como as palavras devem ser grafadas corretamente segundo convenção da escrita é um aspecto importante para a produção textual e a obtenção do objetivo almejado." (p.37)

O conhecimento enciclopédico está relacionado aos conhecimentos de mundo armazenados na memória, compondo uma espécie de enciclopédia na mente do produtor do texto. As autoras apontam que muitos textos de humor utilizam o conhecimento enciclopédico para tornar os textos engraçados, mas o leitor só entenderá se também for conhecedor do assunto. Koch e Elias afirmam que ao escrever.

[...] recorremos constantemente a conhecimentos sobre coisas do mundo que se encontram armazenados em nossa memória, como se tivéssemos uma enciclopédia em nossa mente, constituída de forma personalizada, com base em conhecimentos de que ouvimos falar ou que lemos, ou adquirimos em vivências e experiências variadas. (KOCH; ELIAS, 2012, p. 41). 
Na seção sobre conhecimento de textos, ressaltam que para elaborar um texto, o escritor recorre a conhecimentos sobre o gênero, a estrutura e a finalidade do texto. Utilizam como exemplo uma tirinha sobre a produção de um currículo, em que é questionado se no currículo pode haver informações sobre a autoestima, provocando efeito de humor. Se o leitor não possuir conhecimento sobre o gênero textual currículo, não entenderá o efeito humorístico contido na tirinha.

Nessa última seção, Koch e Elias tratam do conhecimento que representa o foco principal do capítulo, o conhecimento interacional. Aqui, o escritor, com base em seus conhecimentos interacionais, configura o texto de acordo com a intenção de ambos: do produtor, que deseja passar a informação, e do leitor, que busca um texto de fácil entendimento e que the dê o que procura. $\mathrm{O}$ autor, ao desenvolver certos textos, pensa no leitor e na quantidade de informação necessária numa situação comunicativa. Nesse, e nos outros tópicos, as autoras utilizam diversos exemplos para que o leitor entenda, de maneira objetiva, o significado desse conhecimento.

Percebe-se que o capítulo Escrita e interação, de Ingedore Villaça Koch e Vanda Maria Elias, objetiva contribuir de forma significativa para a prática de professores das áreas da linguagem, destacando a importância dessa leitura para professores de outras áreas de conhecimento, para que passem a ter contato com as propriedades textuais, já que isso se faz presente na rotina escolar. A análise realizada pelas autoras é organizada, com relevância para a pesquisa científica. A leitura é fluida, entretanto, em alguns momentos, requer alguns conhecimentos prévios para ser plenamente compreendida. 